\title{
ARTICLES
}

\section{CIVIL JUSTICE IN BRAZIL}

\author{
TERESA ARRUDA ALVIM WAMBIER, \\ Catholic University of São Paulo (São Paulo, Brazil) \\ CASSIO SCARPINELLA BUENO, \\ Catholic University of São Paulo (São Paulo, Brazil)
}

DOI: $10.21684 / 2412-2343-2016-3-4-6-40$

This study deals in a succinct way with the Brazilian model of civil procedural law. There is an historical approach specifically about Portuguese law which was in force in Brazil at the beginning (until 1832), after what there comes a brief description of the judiciary structure (courts and judges) and only then we talk about the scope of civil procedure, its fundamental principles and, in a "law in practice" approach, access to justice. The role of a judge towards deciding "according to statutes and evidence" is analysed and the current importance of case law is deeply focused, mainly according to the new CPC (in force since 2015) and so are appellate proceedings, class actions, enforcement proceedings and ADR. The last items concern the role and the importance of academia, and some interesting cultural observations, where we deal with the very serious crisis, both ethical and economic, that Brazil is living now, in the political sphere. The judiciary branch is now our only hope.

Keywords: Brazilian civil procedural law; case law; role of the judiciary; crisis; trust on the judiciary branch.

Recommended citation: Teresa Arruda Alvim Wambier \& Cassio Scarpinella Bueno, Civil Justice in Brazil, 3(4) BRICS Law Journal 6-40 (2016). 


\section{Table of Contents}

Introduction

\section{Brief History}

2. Courts and Judges

3. Scope of Civil Procedure

4. Structure (Stages) of Civil Procedure

5. Fundamental Principles

6. Access to Justice

7. Forms of Actions

8. Jurisdictions

9. Role of the Judge

10. Evidence

11. Summary Proceedings

12. Appellate Proceedings

13. Class Actions

14. Costs and Funding

15. Enforcement Proceedings

16. Arbitration and ADR

17. The Role of Academia

18. Statistics

19. Comparative Observations

20. Cultural Observations

21. International Matters and BRICS Cooperation in Civil Procedure Perspectives

\section{Conclusion}

\section{Introduction}

This study aims to lay out, in a succinct and didactic manner, the Brazilian model of civil procedural law for jurists specialised in procedural law and other interested parties from abroad.

After a brief review of its history, Brazilian civil procedural law is presented against the backdrop of the Federal Constitution of 1988 and the recent Code of Civil Procedure, Act of Law no. 13.1015, of 16 March 2015, giving special emphasis to the most important novelties introduced by the new code, which came into effect in March 2016. 


\section{Brief History}

In the period prior to Brazil's Independence ( th $^{\text {th }}$ September 1822), Portuguese civil procedure laws, held in the Ordenações Afonsinas (laws passed under King Afonso V) of 1456, Manuelinas (under King Manuel I) of 1521 and Filipinas (under King Philip II) of 1603 , were in force.

After independence, the Ordenações Filipinas remained in effect by Decree of 20 October 1823 of the Constitutional Convention, until such a time as Brazilian laws dealt with the subject. The first genuinely Brazilian legislation on procedural law, according with the teachings of Moacir Lobo da Costa, ${ }^{1}$ can be found in Act of Law of 29 November 1832, the Criminal Procedure Code, whose "Interim provision on the administration of civil justice," an independent part, has 27 articles.

In 1850, still at the time of the Brazilian Empire, Rule no. 737 was drafted and was what we would now call the "Commercial Procedure Code," basically dealing with the regulation of judicial action in disputes arising from the application of the Commercial Code, Act of Law no. 556, of 25 June 1850, which had just been enacted, regulating Art. 27 of the latter. For disputes of a civil nature, that is, not commercial, the Portuguese laws were kept, with the amendments implemented by the aforementioned Interim Provision of the Criminal Procedure Code of 1832 and by a series of laws that have been drafted, since then, dealing with specific topics, that resulted in the drafting of a veritable compilation of civil procedural laws, initiated by virtue of the provisions of Art. 29, § 14, of Law no. 2.033, of 1871, by Councilman Antonio Joaquim Ribas. It is called Consolidação Ribas (Ribas Consolidation), which by virtue of the Imperial Resolution of 28 December 1876, ended up becoming obligatory.

Upon the Proclamation of the Republic, on 15 November 1889, Decree no. 763/ 1890 was drafted extending the rules of Regulation no. $737 / 1850$ to disputes of a civil nature. In 1898, with the enactment of Decree no. 3.084, of 5 November, the "Consolidation of laws relative to Federal Justice" was approved, taking into account the provisions of Decree no. 848, of 11 October 1890, and of Law no. 221, of 20 November 1894. It was thus that a "Federal Justice" was established and consolidated, as well as a specific procedure for cases of interest to the Federal Government, which is explained by the unequivocal influence that the North American government exerted on the founders of the federative republic of Brazil at that historic moment.

The Republican Constitution of 1891, in Arts. 62 and 65, distinguished "federal justice" from "state justice" once and for all - which prevails until today - allowing the member States to legislate on the civil procedure laws that govern the actions of their own judicial bodies (Arts. 34, n. 23, and 65, n. 2). The aforementioned Decree

Moacyr Lobo da Costa, Breve notícia histórica do direito processual civil brasileiro e de sua literatura 5 (São Paulo: Revista dos Tribunais, 1970). 
no. 3.084/1898 was not applicable to the States, only to the Federal Government. While the States did not draft their own Codes, Regulation no. 737/1850 prevailed to govern their own judicial systems.

Gradually, some Brazilian States drafted their own Codes of Civil Procedure, some called "Civil and Commercial Procedure Code." Although there is some controversy in this respect among contemporary legal writers, ${ }^{2}$ the following codes and the year of their enactment are correct: Pará (1905), Rio Grande do Sul (1909), Maranhão (1908), Bahia (1915), Espírito Santo (1915 and 1930), Minas Gerais (1916), Rio de Janeiro (1919), Paraná (1920), Piauí (1920), Sergipe (1920), Ceará (1921), Rio Grande do Norte (1922), Pernambuco (1924), former Federal District (1924), Santa Catarina (1928), São Paulo (1930) and Paraíba (1930). There is no mention of the States of Amazonas, Alagoas, Goiás and Mato Grosso having drafted their own Codes of Civil Procedure, although they had their own laws governing the organisation of the judiciary.

With the promulgation of the Federal Constitution of 1934, the responsibility for legislating on a single civil procedure code was again returned in the hands of the Federal Government (Art. 5, XIX, a), that is, the constitution then established prevented the States from legislating on the matter, attributing the Federal Government exclusive powers to legislate. Then, Art. 11 of the Interim Constitutional Provisions Act established that, with the promulgation of that Constitution, the government would appoint a committee comprising three jurists (two Supreme Court Justices, ex vi of Arts. 63, a, and 73, of the 1934 Constitution, and one lawyer) with the aim of drafting a new national Code of Civil and Commercial Procedure. Paragraph $\S 2$ of the very same interim provision assured that, while the new civil procedural law was not drafted, the state codes would remain in effect.

The drafting of a new Code of Civil Procedure was only possible under the Constitution of 1937, which in Art. 16, XVI, kept the procedural unity (and, consequently, the legislative monopoly) in the hands of the Federal Government. It originated in a bill submitted by Pedro Batista Martins, personally revised by means of several amendments and suggestions sent, since its publication, by the then Minister of Justice, Francisco Campos, with the assistance of Guilherme Estellita. It was finally approved by Decree Law no. 1.608, on 18 September 1939, coming into force as from $1^{\text {st }}$ February 1940.

The greatest criticism that was, historically, made against the 1939 Code of Civil Procedure was that it did not adequately reflect the degree of scientific progress that civil procedure in Europe had already achieved and that, while it was well drafted, it was too theoretical and led to difficulties encountered in its practical application.

In the mid-1960s, a movement arose to reform the Code of Civil Procedure which ended up being handled by Alfredo Buzaid, and led to the "1973 Code of

2 Regarding this discussion, see Código de Processo Civil do Espírito Santo: texto legal e breve notícia histórica, organized by Rodrigo Mazzei, subject of an abstract drafted by one of the co-authors of this article in vol. 420 of Revista Forense (Impresso) (2014). 
Civil Procedure" (Act of Law no. 5.869, of 11 January 1973), which remained in effect until March $2016 .{ }^{3}$

The greatest merit of the 1973 Code is that it provided a high level of systematization of the matter, broadly encompassing all the "science" of civil procedural law produced until that date. A simple consultation of that "Code," even with the innumerable amendments that it underwent during the just over forty years that is was in effect, allows one to have a firm understanding of the scientific ideology that was predominant at the time regarding civil procedural law. It consists of five Books (parts), in the following order: Cognizance procedure (which took up almost half of the Code's provisions), Execution procedure, Provisional procedure, Special procedure and the Final and Temporary Provisions.

Due to the large number of amendments made while the 1973 Code was in effect, the President of the Federal Senate judged that he should appoint a Commission to draw up a Draft Bill for a new Code of Civil Procedure. The President of this Commission was Justice Luiz Fux, currently in the Federal Supreme Court, and his General-Rapporteuse was one of the co-authors of this article, Professor Teresa Arruda Alvim Wambier. The Draft Bill was concluded in the first semester of 2010, submitted to the Federal Senate, which approved the respective Bill at the end of the same year, upon its analysis and amendment by a Commission comprising four procedural lawyers, among them the other co-author of this article. The Senate's Bill was sent for review to the House of Representative - Brazilian legislative procedure is bicameral (Art. 65 of the Federal Constitution) which approved a clean bill in March 2014. Back to the Federal Senate which is compulsory under the sole paragraph of Art. 65 of the Federal Constitution the final version, approved in December 2014 was sent for presidential sanction, culminating in the promulgation of Act of Law no. 13.105, of 16 March 2015.

The new Code of Civil Procedure has a very different structure to its predecessor. It is divided into the General Part and the Special Part and ends with a Book titled "Final and Temporary Provisions."The General Part is, in turn, divided into six Books, namely: Rules of Civil Procedure, Jurisdictional Function, Parties to the Proceedings, Procedural Acts, Provisional Relief and the Commencement, Stay and Dismissal of Proceedings. The Special Part is, in turn, subdivided into three Books, each one containing various Titles. It is pertinent to point out this division of the subject: Book I is titled "Cognizance Procedure and Judgment Enforcement Procedure." Its three Titles and named as follows: "Common Procedure," "Satisfaction of the Judgment" and "Special Procedures." Book II is dedicated to "Execution Procedure" and Book III, "Procedure in the Courts and Means of Challenging Judicial Decisions," being divided

There is a reasonable doubt among Brazilian legal writers regarding the exact date on which the new Code of Civil Procedure, Law no. 13.105, of 16 March 2015, came into effect, whether on 16, 17 or 18 March 2016. For more on this discussion, see Cassio Scarpinella Bueno, Novo Código de Processo Civil anotado 899-900 (2 $2^{\text {nd }}$ ed., São Paulo: Saraiva, 2016); Teresa Arruda Alvim Wambier, Primeiros comentários ao novo Código de Processo Civil 1.703-1.704 (2 ${ }^{\text {nd }}$ ed., São Paulo: Revista dos Tribunais, 2016). 
into two Titles, namely: "Order of Procedures in Courts and Original Jurisdiction Procedures" and "Appeals."

\section{Courts and Judges}

The organisation of the judiciary in Brazil is governed by the Federal Constitution, which has a Chapter on the topic.

The Brazilian Republic's Federative nature leads to the duality between the two jurisdictions, the federal one (which deals mainly with the proceedings in which the Federal Union, and its administrative entities, have an interest, whether as a party or third party) and the state jurisdictions that settle the remaining cases. The organisation of each State is established, based on the federal model, by the respective State Constitutions.

It is Art. 92 of the Federal Constitution that sets forth which bodies make up the judiciary, of which the following pertain to civil procedure: (a) the Federal Supreme Court; $(b)$ the National Council of Justice; $(c)$ the Superior Court of Justice; $(d)$ the Regional Federal Appellate Courts and Federal Judges; $(e)$ the State, Federal District and Territory Courts and Judges.

The Superior Courts have, among others, appellate jurisdiction that characterises them as bodies at the top of the hierarchy of the judiciary, that is, as bodies whose role it is to standardise the interpretation and application of the law throughout Brazil. It is for this very reason that they alone have jurisdiction throughout the whole country, pursuant to Art. 92, § 2, of the Federal Constitution.

The Federal Supreme Court is the highest body of the Brazilian judiciary. It is precisely because of its predominant position in the structure of the judiciary that the Federal Supreme Court, under the head provision of art. 102 of the Federal Constitution, is the "guardian" of the Federal Constitution. The "last say" on the interpretation of Brazilian constitutional law, whose judicial review model is mixed ${ }^{4}$ belongs to the Federal Supreme Court; whether in terms of concentrated control of constitutionality (in the trial of direct actions of unconstitutionality, for example), or in terms of diffuse control (in the hearing of extraordinary appeals, for example). Its headquarters, as set forth in Art. 92, § 1, are in the Federal Capital, Brasília, in accordance with $\S 1$ of Art. 18 of the Federal Constitution.

The composition of the Federal Supreme Court is determined by Art. 101 of the Federal Constitution. It is made up of eleven Justices, selected from among

4 Brazilian law allows the concentrated control of the constitutionality (judicial review) of federal laws before the Federal Supreme Court and, in the case of state and municipal laws before the State Constitutions and the State Courts of Appeals of the State and of the Federal District. It also allows, at any level of jurisdiction, the exercise of the diffuse control of constitutionality. Art. 97 of the Federal Constitution demands that, in these cases, the courts have unconstitutionality declared by the full bench or, where there is procedural delegation, by its special body. 
citizens over the age of thirty-five and under the age of sixty-five, having notable legal knowledge and unblemished reputation, provided they are Brazilian born. The Federal Supreme Court Justices are appointed by the President of the Republic, after the choice is approved by an absolute majority of the Federal Senate.

The jurisdiction of the Federal Supreme Court is governed by Art. 102 of the Federal Constitution. There is an established understanding that its jurisdiction is indisputably that specified in the Federal Constitution, which means that no law, not even the Code of Civil Procedure, can either broaden or restrict it.

The Federal Supreme Court can exercise original jurisdiction, acting as body with a sole instance of jurisdiction. These are the cases provided for in item I of Art. 102 of the Federal Constitution, among which the following are related to civil procedural law, such as: (a) the judicial review of the unconstitutionality of federal or state laws or legislative instruments; the judicial review declaring the constitutionality of a federal law or legislative instrument; and (b) the writ of mandamus and the habeas data against the acts of the President of the Republic, the Boards of the House of Representatives and of the Federal Senate, of the Brazilian Court of Auditors, of the Public Prosecutor's Office and the Federal Supreme Court itself.

Item II of Art. 102 of the Federal Constitution deals with the ordinary appeal jurisdiction of the Federal Supreme Court, that is, it defines the cases in which the Federal Supreme Court acts as a review body of the decisions rendered by another Court. They are cases in which the judicial role performed by the Federal Supreme Court occurs as in a proper court of second instance. The case that is pertinent to civil procedural law is the one provided for in sub-item $a$ of that provision: the writ of mandamus, the habeas data and the injunction decided at a single instance by the Superior Courts, if the plaintiff's request is denied.

Finally, item III of Art. 102 of the Federal Constitution governs the extraordinary appeal jurisdiction of the Federal Supreme Court. These are cases in which the Federal Supreme Court has the diffuse control of constitutionality in so-called extraordinary appeals.

The Superior Court of Justice, being a Superior Court, has jurisdiction in the whole of Brazil, pursuant to Art. 92, §2, of the Federal Constitution. Its seat is in Brasilia, according to $\S 1$ of the same constitutional provision (Art. 18, 11 , of the Federal Constitution).

The composition of the Superior Court of Justice is regulated by Art. 104 of the Federal Constitution. The number of Justices is of, at least, thirty-three, a number which has been observed since its inauguration. They are appointed by the President of the Republic, chosen from among Brazilians who are over thirty-five and under sixty-five years of age, have remarkable legal knowledge and flawless reputation, after the choice is approved by an absolute majority of the Federal Senate (Art. 104, sole paragraph, of the Federal Constitution).

Its make-up is diversified because, according to items I and II of the sole paragraph of Art. 104 of the Federal Constitution, one third of the Superior Court of Justice 
is to be made up of judges from the Regional Federal Appellate Courts and one third from among judges from the State courts of Appeals, nominated in a triple list drawn up by the Court itself, and the remaining third, in equal parts, from among lawyers and members of the Federal, State, Federal District and Territories' Public Prosecutor's Offices, alternately, nominated in accordance with Art. 94 of the Federal Constitution.

The jurisdiction of the Superior Court of Justice is regulated by Art. 105 of the Federal Constitution. Here too the prevalent understanding is that the law can neither restrict it not broaden it. It is a matter in which the Constitution is emphatic, not allowing the modification by an infraconstitutional act, not even by the Code of Civil Procedure.

An analysis of the jurisdiction of the Superior Court of Justice reveals that, like that of the Federal Supreme Court, there is a distinction between the original, ordinary appeal and special appeal jurisdiction.

The cases where the Superior Court of Justice acts as a "court of first instance," that is, in cases where it exercises its original jurisdiction, with regard to civil procedural law and according to item I of Art. 105 of the Federal Constitution, are those such as: (a) writs of mandamus and habeas data against acts of a Minister of State, Navy, Army and Air Force Commanders, or of the Court itself; and (b) conflicts of jurisdiction between any courts, but for the provisions of Art. 102, I, 0 , of the Federal Constitution, as well as between the court and judges not linked to the Superior Court of Justice and between judges linked to various courts.

Ordinary appeal jurisdiction is provided for in item II of Art. 105 of the Federal Constitution. The cases that are pertinent to civil procedural law are the following: (a) writs of mandamus decided at a single instance by the Regional Federal Appellate Courts or by the State, Federal District and Territory Courts, in case of an adverse decision; and (b) cases in which one of the parties is a foreign government or an international body, on one side and, on the other, a Municipal District or person resident or domiciled in the Country.

Finally, the special appeal jurisdiction of the Superior Court of Justice is provided for in Art. 105, III, of the Federal Constitution. The rule establishes the cases in which a "special appeal" is appropriate and is filed in "cases decided, at a single or last instance, by the Federal Regional Appellate Courts or by the State, Federal District and Territory Courts when the appealed decision violates federal law: (a) in contravention of a federal treaty or law, or denies them effectiveness; $(b)$ judges to be valid an act of the local government that is contradicted by federal law; and (c) gives federal law an interpretation that is divergent to one attributed by another court." The role performed by the Superior Court of Justice in these cases, like that performed by the Federal Supreme Court for the purposes of extraordinary appeals, is that of an overlapping body, aimed, mainly, at the standardisation of the interpretation and application of federal infra-constitutional law throughout Brazil. 
In Brazil, the Federal Justice system was established right after the proclamation of the Republic, under Art. 1 of Decree no. 848, of 11 October 1890. This initiative was written into the constitution in Art. 55 of the 1891 Constitution, which referred to the "Judicial Branch of the Federal Government" comprising "a Federal Supreme Court, with seat in the Capital of the Republic, and as many Judges and Federal Courts, spread throughout the country, as the Congress may determine."

It tries claims in which the parties are federal public legal entities (personal jurisdiction) and certain subject matters that, being deemed relevant, it was considered should be tried by the Federal Courts (subject-matter jurisdiction).

According to Art. 106 of the Federal Constitution, the Federal Justice system comprises Regional Federal Appellate Court and Federal Judges.

Art. 109 of the Federal Constitution defines the jurisdiction of the Federal Courts of first instance, that is, the subject matters that the federal judges, who make up the first instance of the federal justice system, will try. The cases relevant to civil procedural law are the following: (a) cases in which the federal government, government agency of federal public company are interested parties as plaintiffs, defendants, assistants or opponents, except for those relative to bankruptcy, occupational accidents and those subject to the Electoral Courts and Labour Courts; $(b)$ cases relative to human rights, observing, in this case, the "transfer of jurisdiction incident" to be analysed by the Superior Court of Justice, referred to in $\S 5$ of Art. 109; (c) writs of mandamus and habeas data against the acts of a federal authority, with the exception of the cases under the jurisdiction of the federal courts; and $(d)$ disputes regarding indigenous people's rights.

The Federal Constitution also deals, as already emphasised, with the outlining of the basic model of the State and Federal District Courts. In accordance with its Art. 125, head provision, the organisation of the state and federal district courts are to observe the "principles established in this Constitution", also taking into account the express guidelines found in its paragraphs.

The National Council of Justice was established by Constitutional Amendment no. 45/2004. Its seat is in Brasília (Art. 18, §1, combined with Art. 92, $\S 1$, of the Federal Constitution). Although referred to in Art. 92 of the Federal Constitution as a court, its role is a merely administrative one.

According to Art. 103-B, head provision, of the Federal Constitution, the wording of EC no. 61/2009, the National Council of Justice is made up of fifteen members. They have a two-year mandate, with the possibility of being extended for two additional years. It is a diverse body, with their members originating from the most diverse bodies of the Brazilian justice system. Its composition is as follows: President of the Federal Supreme Court, one Justice from Superior Court of Justice, nominated by the respective court; one Justice from the Superior Labour Court, nominated by the respective court; one appellate judge from the Court of Appeals, nominated by the 
Federal Supreme Court; a state judge, nominated by the Federal Supreme Court; an appellate judge from the Regional Federal Appellate Court, nominated by the Superior Court of Justice; a federal judge, nominated by the Superior Court of Justice; a judge from the Regional Appellate Labour Court, nominated by the Superior Labour Court; a labour judge, nominated by the Superior Labour Court; a member of the Federal Prosecutor's Office, nominated by the Federal Attorney General; a member of the State Prosecutor's Office, chosen by the Federal Attorney General from among the names nominated by competent authority of each state institution; two lawyers, nominated by the Federal Council of the Brazilian Bar Association; two citizens, with notable knowledge of the law and flawless reputation, one nominated by the House of Representatives and another by the Federal Senate.

The appointment of the members of the Council, with the exception of the President of the Federal Supreme Court, is made by the President of the Republic, after having been approved by an absolute majority of the Federal Senate (Art. 103-B, $\S 2$, of the Federal Constitution).

\section{Scope of Civil Procedure}

The purpose of civil courts in Brazil, whose activities are governed by civil procedure, is to solve disputes between individuals, legal entities and natural persons, and also to solve problems generated by inappropriate activities of the government. Nowadays, we do have neutral and impartial judges. Nevertheless, circumstances, such as the huge amount of suits and appeals, and also a considerable and undesirable level of bureaucracy, sometimes create difficulties for the judiciary to achieve high levels of performance.

In the last decade, some situations encompassed by judiciary activities, hence governed by civil procedural rules, were transferred to other organs. There were attempts to simplify some of the procedures, as was noted with regard to the specific cases of amicable divorce, probate proceedings and acquisition by prescription, which can be processed without the intervention of a judge and before an extrajudicial registrar/notary.

Finally, it should be noted that in Brazil we have a mechanism (judicial proceedings) that is very similar to the judicial review, governed by civil procedure. Our Supreme Court verifies, in a specific type of action or proceedings, known as Ação Declaratória de Inconstitucionalidade, that a statutory law or norm does not violate or contradict the Federal Constitution. Legal writers say call this a no-party, no-claim and no-defence lawsuit.

But apart from that, the main and obvious task of civil justice in Brazil is to resolve disputes. It is considered that for the judiciary to play its role (resolving disputes) in an effective way, it has to have three functions: 
1. to create or to maintain practical conditions favourable to the effectiveness ${ }^{5}$ of a judicial decision, i.e., in order for a judicial decision to be able to generate desirable effects;

2. to state if the claimant has rights (which is a declaratory function); and

3. to carry out enforcement activities. ${ }^{6}$

\section{Structure (Stages) of Civil Procedure}

As a rule, Brazilian civil procedure starts before the courts of first instance, made up of trial judges.

In such cases, access to the courts of second instance is assured by the appeal proper/appeal from final judgment, an appeal against the final judgment. The new Code of Civil Procedure also states that certain interlocutory decisions, i.e. rendered during the proceedings, be immediately challenged by a court with jurisdiction, by means of an appeal called an "agravo de instrumento" or interlocutory appeal.' Both appeals are heard by three judges who are called, both in the State and Federal Courts, Desembargadores or appellate judges. ${ }^{8}$

After the decision of the courts of second instance is rendered, whenever there is a violation of the provisions of the Federal Constitution or of federal laws, either an extraordinary appeal or a special appeal may be lodged, before the Federal Supreme Court or before the Superior Court of Justice respectively. The rule is that these appeals be heard by five Ministros (the title given to the Justices of these Courts), with the aforementioned Art. 932 of the new Code of Civil Procedure also being applicable to them, in fact, a very common practice.

These courts, when hearing these appeals, play the role of the third or fourth instances. The special (Superior Court of Justice) and extraordinary (Federal Supreme

5 The main concern of legal authors is to provide a fair trial with fair results (minimal standards related to substantial due process of law) through interpretation of statutory law and creation of new legal mechanisms. Cândido Rangel Dinamarco, Instituições de direito processual civil. Vol. 1 (6 ${ }^{\text {th }}$ ed., São Paulo: Malheiros, 2009), at chs. 1 to 5.

6 José Carlos Barbosa Moreira says exactly that, also saying that this corresponds to the classification of the types of lawsuits - cognition, enforcement and urgent measures. José Carlos Barbosa Moreira, O Novo Processo Civil Brasileiro 3 ( $25^{\text {th }}$ ed., Rio de Janeiro: Forense, 2007).

7 For this purpose, it is should be emphasised that the previous Code of 1973, admitted the ability of appeal against all interlocutory decisions, though not all immediately. The radical change in the rules governing the ability to appeal against such decisions has aroused intense discussion among jurists, as revealed by the diverging opinions voiced by the authors of this article. To this effect, see Scarpinella Bueno, Novo Código de Processo Civil anotado, at 839-841; Cassio Scarpinella Bueno, Manual de direito processual civil 690-692 ( $2^{\text {nd }}$ ed., São Paulo: Saraiva, 2016); Wambier 2016, at 1.612.

8 In exceptional cases, set forth in Art. 932 of the New Code of Civil Procedure, a single judge may act in the courts. In such cases, however, there is an express provision for an appeal (known as an "internal interlocutory appeal") in order to render possible the control of the performance of a single judge before the collective body with jurisdiction. This is an extract of Art. 1.021 of the new Code. 
Court) appeals decide on points of law, although they do not prevent a retrial of the case by the courts when a violation of the Federal Constitution or of federal laws is ascertained.

The State and Federal Constitutions establish, exceptionally, what is known as "foro por prerrogativa de função," i.e. jurisdictional prerogative, for certain politicians or government agents. The most recent example was that of the numerous writs of mandamus filed against the appointment, by the President of the Republic, of former President Luis Inácio Lula da Silva as Chief of Staff, which, to many people, was done in order to hamper the existing criminal investigation against him, in course within Carwash Operation, in the first instance. In such cases, access to the Superior Court is assured by the Federal Constitution itself, either by means of an ordinary appeal or by the aforementioned extraordinary or special appeals.

\section{Fundamental Principles}

The new Code of Civil Procedure, and, in fact, all Brazilian civil procedural law, are heavily influenced by what one of the authors of this article has called "the constitutional model of civil procedural law." The $1^{\text {st }}$ article of the new Code reads as follows: "Civil procedure shall be regulated, governed and interpreted in accordance with the values and fundamental principles established by the Constitution of the Federative Republic of Brazil, in accordance with the provisions of this Code."

From a constitutional perspective, the following principles that inspired civil procedure should be noted: access to justice (Art. 5, XXXV, of the Federal Constitution), due process of law (Art. 5, LIV, of the Federal Constitution), audi alteram partem (Art. 5, $\mathrm{LV}$, of the Federal Constitution), the right to present evidence and to be heard (Art. 5, $\mathrm{LV}$, of the Federal Constitution), court with jurisdiction (Art. 5, XXXVII and LIII, of the Federal Constitution), impartiality (Art. 95 of the Federal Constitution), two-tiered system (implicit principle), collective responsibility in the courts (Art. 96, I, a, of the Federal Constitution), and so many others.

The first articles of the new Code of Civil Procedure are connected to several of these principles. They deal with, for example, the principle of free disposition (maxime de disposition) in Art. 2, of the means of alternative dispute resolution in Art. 3, of the reasonable duration of proceedings in Art. 4, of the principle of audi alteram partem in the sense of allowing cooperation/participation in Art. 6, of the principle of equality in Art. 7, in Art. 10 and of publicity of reasoning of judicial decisions in Art. 11.

Furthermore, there are other principles in the new Code of Civil Procedure that draw our attention, such as: the preference for trial on the merits (Arts. 139, IX, and

9 This is shown at greater length in Cassio Scarpinella Bueno, Curso sistematizado de direito processual civil. Vol. $1111-244$ ( ${ }^{\text {th }}$ ed., São Paulo: Saraiva, 2014), and, more recently, in a concise manner, in Scarpinella Bueno, Manual de direito processual civil, at 41-65. 
317); the atypicality of enforcement mechanisms (Art. 139, IV); the atypicality of the production of evidence (Art. 369) and that of the attainment of evidence (Art. 371).

The Dispositions Maxime is also adopted..$^{10}$ The parties decide as to the commencement of the proceedings and their scope in ordinary matters. This rule has a long tradition and is often elevated to the status of a fundamental principle. Courts cannot ${ }^{11}$ initiate proceedings or change their scope. The possibility of cognitio ex officio during proceedings is extremely rare in Brazilian law. Judges can determine ex officio some procedural matters such as lack of standing (lack of legitimatio ad causam and ad processum) or res judicata.

As a rule, a judge is limited by the claim ${ }^{12}$ presented by the plaintiff, by the terms of the defence and by the evidence brought to the proceedings, which, by the way, can be brought as a result of a judge's request, ${ }^{13}$ complementing the parties' activities.

The principle iura novit curia is also adopted in Brazil. A judge is limited as to the facts brought by the parties but not as to the legal aspects. He or she can win on a very different basis as far as the law is concerned. ${ }^{14}$

\section{Access to Justice}

Access to Justice in Brazil is a reality nowadays. In fact, ADR is still at their very beginning. Arbitration is normally used in Brazil to solve disputes between huge Companies, involving considerable amounts of money. So, in fact, Arbitration has nothing to do with access to Justice.

To obtain legal aid, it suffices to declare indigence/poverty, costs are not high, and there is an organ of the state which provides pro bono lawyers for those who cannot pay (Public Defender).

Besides common courts, there are those which are specialized in lawsuits involving small claims/amounts of money whose proceedings are fast and have no formalities.

10 According to Brazilian legal writers, the "Dispositions maxime" means also that a judge depends on the initiative of the parties to produce evidence, i.e., on which facts parties have alleged. ludex secundum alega et probata partium iudicare debet. Antônio Carlos de Araújo Cintra, Teoria geral do processo 64 ( $25^{\text {th }}$ ed., São Paulo: Malheiros, 2009).

11 The "Dispositions maxime" has very few exceptions in Brazilian law, which are in fact not really significant. José Carlos Barbosa Moreira, Reformas processuais e poderes do juiz, 6(22) Revista da EMERJ 57 (2004).

12 In fact, the petitum expresses simultaneously the object of the claim and what the party expects from the judiciary. Luiz Rodrigues Wambier et al., Curso avançado de processo civil. Vol. 1297 (9 $9^{\text {th }}$ ed., São Paulo: Revista dos Tribunais, 2007).

13 This corresponds to a very recent trend in Brazilian law: a judge is considered to have more powers or a stronger power in what concerns the production of evidence. This is considered to be a valid path to reach real equality between the parties. José Roberto dos Santos Bedaque, Direito e processo: influência do direito material sobre o processo 72 ( $2^{\text {nd }}$ ed., São Paulo: Revista dos Tribunais, 1994.

14 Fredie Didier Jr., Curso de direito processual civil. Vol. 1290 (10 ${ }^{\text {th }}$ ed., Salvador: JusPodivum, 2008). 


\section{Forms of Actions}

The 2015 Code of Civil Procedure makes a clear distinction between what it calls "common procedure" and "special procedures," the former being governed by the provisions of Arts. 318 to 512 of the Code itself. The special procedures, besides the various procedures governed by Arts. 539 to 770 of the Code, which divides them into "litigious" and "nonlitigious", 15 are governed by several uncodified laws, of which, by way of illustration, it is worth mentioning the following: the laws governing the leasing of urban property, condemnation, support, writs of mandamus and rules on class actions in general.

Common procedure must be understood as a sequence of acts ranging from the complaint to the entering of the judgment.

The 2015 Code of Civil Procedure includes the rules regarding the drafting of the complaint which, if accepted, will lead to the service of process upon the defendant so that, as a rule, he or she will appear at the conciliation and mediation hearing. Only when said hearing is impossible or thwarted, or even at the request of the parties, will the defendant's deadline to submit his or her defence (answer) start running. This is also the defendant's opportunity, if so inclined, to file a counterclaim against the plaintiff in the same suit.

Thereafter, common procedure esters the stage known as "judgment according to the state of the proceedings." In accordance with the peculiarities of each case, it is up to the judge, at this stage, to enter a summary judgement (preliminary judgment on the merits) or, merely of part of the merits (summary judgment with partial adjudication on the merits/pleadings, an important novelty introduced by the 2015 (PC) or dismiss the case without prejudice or, still, cure and organise the proceedings to make viable the start of the evidentiary stage, in which evidence will be produced.

Then, there is the entering of the judgment that is appealable by an appeal known as apelação, or appeal proper, which, as a rule, prevents enforcement of the judgment, i.e. it stays the execution. ${ }^{16}$

When the judgment becomes final, or when an appeal that does not stay the execution is filed - which, despite the apelação, is the norm for other types of appeal - the interested party may start the enforcement of the judgement, whether permanent or provisional, in accordance with the prior res judicata judgment.

With regard to the special procedures, it should be noted that the cases governed by the 2015 Code of Civil Procedure as litigious proceedings are the following: action

15 The distinction and nomenclature are heavily criticised by Brazilian jurists. So much so that the Draft Bill of the new Code of Civil Procedure rejected them in favour of others, which distinguished litigious and nonlitigious procedures.

16 This was a rather controversial topic throughout the legislative process that culminated in the new Code of Civil Procedure, the traditional rule of Brazilian law prevailing nonetheless. 
for payment into court, action to demand accounts, actions to recover possession, action for the partition and demarcation of private land, action for partial dissolution of a corporation, probate proceedings, third party motions to stay proceedings, opposition proceedings, proof of claim proceedings; family cases, action on a nonexecutory written instrument, ratification of statutory lien, general average regulation and recovery of case records.

As cases of nonlitigious proceedings, the special procedures regulated by the 2015 Code of Civil Procedure are the following: notifications and written requests of performance, judicial alienation/attachment, amicable divorce and separation, amicable dissolution of a civil union, change of the marriage regime, testaments and codicils, unclaimed estates, assets of the absent person, adjudication of mental incapacity, common provisions regarding guardianship, organization and inspection of foundations, and ratification of sea protests and procedures performed at sea with witness statements.

\section{Jurisdictions}

In Brazilian law, the so-called single jurisdiction prevails, inspired by the North American system, and it thus understood that there are no administrative jurisdictional courts.

Therefore, all administrative acts may, as a rule, be reviewed by the judicial branch, which even has specialized mechanisms to render such control viable, such as the "writ of mandamus," the "citizen suit" and the "action against misconduct in public office," which has been extensively used in the so-called Carwash Operation focused on acts of corruption committed to the detriment of one of the main Brazilian companies (whose majority shareholder if the Federal Government), Petrobrás.

There is a growing trend in Brazilian law, mainly from the perspective of jurists, to argue that the country's judiciary should also be responsible for controlling "public policies," in that way enabling the judiciary to concretely modify certain policies established by politicians and/or administrators, correct the course of those that were previously implemented or even determine that they be effectively implemented. ${ }^{7}$

With regard to jurisdictional competence, one should emphasise the specific courts for the resolution of labour, electoral and military disputes, which follow the same logic as the federal and state courts.

\footnotetext{
17 Prof. Ada Pellegrini Grinover, Honorary President of Associação Internacional de Direito Processual
} and of Instituto Brasileiro de Direito Processual, is tireless defender of this movement. 


\section{Role of the Judge}

The role of a civil judge is, according to most Brazilian legal writers (academics), to solve conflicts or disputes ${ }^{18}$ between $A$ and $B^{19}$ in accordance with the law. ${ }^{20}$ When we say "in accordance with the law," in Brazil we mean statutory law, as Brazil is a civil law jurisdiction. ${ }^{21}$ This is a typical academic approach.

Nevertheless, on many occasions civil judges, in solving problems generated by inappropriate activity of the government ${ }^{22}$ have to decide based on norms which are verbally formulated with the use of vague or cloudy concepts and legal principles, which are sometimes not even written. In statutory law, these cases are normally solved in the context of class actions. ${ }^{23}$

It is exactly in this kind of conflict between society, represented by one of its bodies, and the government, that the serious issue of judicial activism arises. Judges have to "create" solutions, ways to solve problems, because in most cases they have to find a way to solve conflicts which were not previously contemplated by the legislator. Many times judges act as if they were part of the executive branch of the government (pouvoir exécutif). ${ }^{24}$

Judges sometimes act as if they were the legislative branch of the government because they have to solve disputes having the last word on a very important legal issue (quaestio juris). Usually, these disputes involve a large group of people (class actions), but not necessarily. In these conflicts or disputes, the final word of the

18 Our Code of Civil Procedure was conceived in a very individualistic society. Thus, its structure is in fact suitable to solve disputes between individuals and not group conflicts. Teori Albino Zavascki, Reforma do sistema processual civil brasileiro e a reclassificação da tutela jurisdicional, 88 Revista de Processo 173 (1997).

19 Although, as will be seen below, we have a very well developed class action system, it is, however, not in our CPC.

20 In fact, contemporary legal writers recognise that civil procedure also has social and political goals. It serves to allow individuals to exercise their citizenship. Dinamarco 2009, at 135.

21 Although there are some typical characteristics of common law systems: e.g., small claims are treated in a special fashion and, as was said before, we also have class actions, inspired by the North American system. José Carlos Barbosa Moreira, Notas sobre alguns aspectos do processo (civil e penal) nos países anglo-saxônicos, 92 Revista de Processo 87 (1998).

22 In fact, inappropriate activity of the government generates lawsuits and also their conduct during proceedings is not always ideal, but there are unfortunately not very reliable statistics on this problem.

23 Nowadays, there are often lawsuits (normally class actions, but not only) against the government to obtain medicines (RE 607381/SC - STF) or a specific medical treatment (REsp 872733/SP - STJ) or the restructuring of hospitals and maternities for them to respond in an adequate fashion to the needs of the underprivileged (REsp 1041197/MS - STJ).

24 The judiciary can, exceptionally, play this role, mainly when the government denies citizens access to essential goods, in relation to their social rights (Arguição de Descumprimento de Preceito Fundamental n० 45). 
judiciary is law (completes the real meaning of the norm) and prevents new disputes involving the same topic.

This is a very relevant new role of the judiciary, mainly related to the courts which are at the top of the structure of the judiciary (Supremo Tribunal Federal and Superior Tribunal de Justiça).

In the year of 2004, there was an amendment to our Federal Constitution, which included in our legal system what we call "súmula vinculante."This could be roughly translated as "binding precedent" but it is not at all a precise translation, because, in fact, it is not a precedent: it is a "summary" of a line of precedents issued by the STF, which denotes its "opinion" on a specific "quaestio juris," and must necessarily be respected or adopted by all other courts and judges, and by the executive branch.

This legal concept, "súmula vinculante," is the most expressive example of this last function or role of the judiciary: "creating" law.

Thus, since the abovementioned amendment, the Supreme Court can, in a very peculiar way, create law, but always respecting the formal limits established by the Brazilian Constitution, which provides a very specific procedure that must be followed. The "precedent" is said to be "binding," because, as said before, other judges, courts and the Government must obey what has been decided by the Supreme Court, as if its decision were a rule. Of course, to understand this trait of the Brazilian legal system, it is convenient to remember that Brazil is a civil law jurisdiction, so we are not familiar with the stare decisis doctrine as in common law systems.

This peculiar legislative activity of the Supreme Court can take place when a controversy over a constitutional issue creates a state of uncertainty and there is a large number of claims with the same cause of action.

The Brazilian Constitution also provides a very peculiar procedure that can be used, in case a judge, court or anybody in the Government does not respect the "súmula vinculante" of the Supreme Court. It is a special claim, called Reclamação, that one can file before the Supreme Court (STF) and that has, as cause of action, the disobedience of a "súmula vinculante." But there are some restrictions, for instance: this claim cannot be filed, when the disobedience happens in a judicial act, which may be challenged by an appeal to the very same STF, according to procedural law. ${ }^{25}$

\section{Evidence}

Art. 5, LVl, of the Brazilian Federal Constitution assures the freedom of the means of production of evidence provided it is not unlawful or obtained unlawfully.

On an infra-constitutional level, the corresponding provision is found in Art. 369 of the new Code of Civil Procedure, worded thus: "The parties have the right to employ

25 Thus: Rcl 11859 AgR, Relator Ministro Teori Zavascki, Tribunal Pleno, tried on 23/05/2013, published on $14 / 06 / 2013$. 
all the legal, as well as morally legitimate, means, even if they are not specified in this Code, to prove the truth of the facts on which the claim or the defence is based and effectively convince the judge."

Significant novelties have been introduced by the 2015 Code, notably among them are: the admissibility of the early production of evidence regardless of the urgency (Arts. 381 to 383), the provision for "notarial minutes" to be used as evidence (Art. 384) and the extinction of the "indirect (through the judge) questioning" of witnesses (Art. 459, head provision), allowing the lawyer to question the witness directly, always under the supervision of a judge. The 2015 CPC also innovates by providing that it is the lawyer who must, as a rule, inform or subpoena the witnesses regarding the trial (Art. 455, head provision).

Oral testimony is to be produced within the scope of the trial, which will be scheduled in the pretrial order declaring the case to be ready for trial (Art. 357, V). Namely: testimony of the party (testimony of the parties themselves, with the main objective of confessing the facts that are unfavourable to them), testimonial evidence (testimony of third parties regarding the relevant facts of the case) and testimony of experts (either substituting or complementing expert evidence).

Documentary evidence, as a rule, must accompany the complaint and the answer. Expert evidence aims to investigate the technical facts, which are beyond the scope of the judge's expertise.

In Brazilian law, there is no evidence scoring system. It is, therefore, up to the judge to rate it in each particular case, a statement of reasons for the respective decision being indispensable.

Furthermore, one of most delicate issues in Brazilian legal theory concerns the balance between the wish to establish the facts correctly and the need to provide effective protection of rights in a reasonable period of time. The importance of the search for truth in the proceedings is recognized, but it is also admitted that this search cannot compromise the reasonable duration of proceedings ${ }^{26}$ On the other hand, one cannot state that, in Brazilian civil procedure, there is an absolute and irrevocable choice between either option. ${ }^{27}$ In recent decades, perceptible efforts have been made by Brazilian legislators to balance the two needs, that is, to combine speed and accuracy.

26 One of the goals of Brazilian civil procedure is to reach the truth, but certainly not the only one, for proceedings cannot last forever. José Manoel de Arruda Alvim, Manual de direito processual civil. Vol. 2 379 ( $9^{\text {th }}$ ed., São Paulo: Revista dos Tribunais, 2005).

27 The various imperative deadlines of Brazilian civil procedure can be considered a device or a method to avoid eternal proceedings. Egas Dirceu Moniz de Aragão, Comentários ao Código de Processo Civil. Vol. 299 ( $2^{\text {nd }}$ ed., Rio de Janeiro: Forense, 1976). To avoid eternal proceedings, there is a provision in Brazilian civil procedure saying that if the defendant does not respond within a certain deadline, facts alleged by the claimant can be considered true by a judge, depending on the context and on certain conditions. It is a technique to speed up proceedings. Cândido Rangel Dinamarco, Fundamentos do processo civil moderno 951 ( $3^{\text {rd }}$ ed., São Paulo: Malheiros, 2000). 
In some situations, the legislator favours the timeliness of relief and allows the party to benefit in advance from the effects which would normally only be attained in the final judgement. However, a judicial provision on these terms is an exception and presupposes the fulfilment of some prerequisites, among which is the risk of losses being incurred by the party who claims the rights and the existence of elements that, at least, appear to prove the claimed rights.

Today, Brazilian law is generous with remedies based on incomplete cognition ${ }^{28}$ (fumus boni iuris). That means that a judge can advance the claimant the whole (or just a part of the) effect of the final judgment or decision, if there is urgency (periculum in mora). Normally, these effects are entirely or partly advanced under the condition of the possibility that the situation could turn, in case of loss, to the status quo ante. If these prerequisites are not fulfilled, the party must generally wait for the final judgement, based on exhaustive cognition, to then be awarded the claimed rights.

However, upon the enactment of a new bill currently under debate by the legislature, Brazilian civil procedure will undergo significant changes with regard to interlocutory relief. In fact, the new draft bill primarily sets forth that, regardless of the practical effects obtained from interlocutory relief, there will be no need to file an independent lawsuit for the party to request it. Many other changes will come about as a result.

Once interlocutory relief has been granted, based on summary cognizance, the defendant is summoned and can challenge it. Should the defendant oppose the relief granted the plaintiff, he/she has a period of 30 days (unless otherwise determined by a judge) within which to make a main claim, which will be decided by the judge upon thorough and exhaustive appreciation of the merits. However, if the defendant does not manifest himself/herself, the case will be dismissed and the decision based on summary cognizance will remain in effect for an indeterminate period. It is up to the defendant to stop such effects by filing an action for that purpose. In said action, the judge will analyse the pertinent issues based on a thorough and exhaustive appreciation of the merits, respecting adversary proceedings and the right to be heard. ${ }^{29}$ It is said that there will thus be a stabilisation of interlocutory relief in Brazilian civil procedure.

The procedure briefly described above is not foreign to the procedural legislation currently in effect in Brazil. There are, in fact, similarities between this procedure and an action on an unenforceable written instrument, currently governed by items 1102-A to 1102-C, of the CPC, such as:

1. the rendering of the decision to grant interlocutory relief based on summary cognizance;

28 Procedimento monitório. José Rogério Cruz e Tucci, Tempo e processo (São Paulo: Revista dos Tribunais, 1997), passim.

29 Athos Gusmão Carneiro, O novo Código de Processo Civil: breve análise do projeto revisado no Senado, 194 Revista de Processo 139 (2011). 
2. the possibility of making a decision on the basis of the inactivity of the defendant, producing effects until there is an opposing decision, by means of an independent action filed subsequently by the defendant; and

3. the absence of res judicata, with regard to the interlocutory relief decision, even when it acquires stability due to the inactivity of the defendant.

It is precisely due to such similarities that some envisage an expansion of actions on unenforceable written instruments in the amendments relating to the abovementioned interlocutory relief. ${ }^{30}$

\section{Summary Proceedings}

The new Code of Civil Procedure innovates in relation to the previous one, from 1973, by joining what Brazilian law viewed in a dichotomous manner, even from a formal point of view, making a distinction between processo cautelar, or provisional remedy, and tutela antecipada, or interlocutory relief. For Brazilian law, provisional remedies have (and continue to have in the systematics of the new Code) the sole purpose of assuring a right, rendering the timely achievement of said right possible. Interlocutory relief, on the other hand, renders possible the immediate satisfaction of the right.

It is thus that Book V of the General Part of the new Code of Civil Procedure is dedicated to what became known as "tutela provisória," or provisional relief (Arts. 294 to 311). These are rules that allow, in a general way, the granting, in advance or incidentally, measures capable of preserving or satisfying the right in dispute. The grounds for such measures may be urgency (in relation to actual periculum in mora to justify the measure) or evidence (the more evident right of one of the parties based on the frame of reference provided in Art. 311). ${ }^{31}$

Differently to the 1973 Code of Civil Procedure, the new Code does not specify which measures may be granted in order to achieve those goals. It is therefore correct to argue that, in the new Code, "the general power of the provisional remedy" (Art. 301) and the "general power of the interlocutory relief" (Art. 297) prevail in place of the now revoked specific provisional proceedings.

Another important novelty introduced by the Code of Civil Procedure of 2015 is the possibility of the interlocutory relief granted in a preliminary decision becoming

30 Eduardo Talamini, Tutela de urgência no projeto de novo Código de Processo Civil: a estabilização da medida urgente e a "monitorização" do processo civil brasileiro, 209 Revista de Processo 13 (2012).

31 The frames of reference are the following: $(a)$ abuse of the right to a defence and clearly frivolous manifesto by the party; $(b)$ allegations of fact based only on documental evidence and argument based on repeat claims or binding precedent; (c) claim for repossession based on documental evidence of the deposit agreement; and $(d)$ complaint producing sufficient documental evidence of the facts that constitute the plaintiff's right, and against which the defendant does not does file evidence capable of generating reasonable doubt. 
permanent when the defendant does not file an appeal against it. In this case, both the plaintiff and the defendant may, if they so wish, file a claim against the opposing party seeking a decision based on full cognizance and able to produce res judicata effect. However, while this does not occur, the effects of the decision that granted the relief are preserved.

\section{Appellate Proceedings}

Title II of Book III of the Special Part of the new Code of Civil Procedure deals with appeals. Art. 994 names the applicable appeals: apelação (appeal proper), agravo de instrument (interlocutory appeal), agravo interno (interlocutory appeal to the same court/internal interlocutory appeal), embargos de declaração (motion for clarification), recurso ordinário (ordinary appeal), recurso especial (special appeal to the Superior Court of Justice), recurso extraordinário (extraordinary appeal to the Federal Supreme Court), agravo em recurso especial ou extraordinário (motion in special or extraordinary appeal) and embargos de divergência (appeal against a divergent decision).

The deadline for filing and answering the appeals is fifteen (15) working days, with the exception of motions for clarification whose deadline is five (5) working days, as stated in $\S 5$ of Art. 1.003.

As already disclosed, the proposal of the Draft Bill to set aside the stay of execution as a rule of the appeal proper (recurso de apelação) (Art. 1.012, head provision), which had been admitted by the Federal Senate Bill of 2010, did not prevail in the 2015 CPC. The items of $\S 1$ of Art. 1.012 set forth the exceptions to that rule, i.e. the cases in which the appeal proper does not produce the effect of staying the execution along the lines of Art. 520 of the 1973 CPC, - justifying, therefore, the immediate satisfaction of the judgment.

For all other appeals, the rule that appeals "do not impede the enforceability of the decision, unless otherwise provided for by law or by a court decision" (Art. 995, caput) prevails, i.e. they do not produce the effect of "staying the execution."The sole paragraph of Art. 995 establishes the conditions for, as the case may be, the effect of staying the execution be determined by the judge-rapporteur "if there is a risk of grave or irreparable harm arising from its immediate enforcement, and if it is shown that there is a high probability of the appeal being granted."The 2015 CPC therefore admits the possibility of granting, ope judicis (by the power of the judge) rather than the ope legis (by the power of the law) tradition of Brazilian law, the stay of execution, but for the, unfounded, exception of the case of the appeal proper, recurso de apelação.

The appeal proper is the appropriate appeal against a judgment. It must also target all the interlocutory decisions that, in accordance with Art. 1.015 of the new CPC, do not admit an immediate appeal, the so-called interlocutory appeal (Art. 1.009, $\S 1$ and 2). 
The interlocutory appeal is a mechanism aimed at the interlocutory decisions expressly provided for in Art. 1.015 of the 2015 CPC or those expressly established by other laws.

The internal interlocutory appeal is expressly provided for in Art. 1.021, thus enabling, at the request of the appellant, all decisions rendered by a single judge within the scope of the court to be reviewed by a panel of judges.

Motions of clarification are a type of appeal that aims to clarify obscurity or vagueness, rectify omissions or contradictions and correct significant errors frequently found in court decisions.

The ordinary appeal is the one that can be lodged when the decision is unfavourable to the applicant for writs of mandamus, habeas corpus, habeas data and other situations set forth by the constitution when those proceedings have to be originally filed before a court, subject to the authority involved.

The extraordinary appeal is the one that allows the Federal Supreme Court, in the exercise of its broad control of constitutionality, to oppose the decisions of other Brazilian courts that interpret the Federal Constitution.

The special appeal is the means by which the Superior Court of Justice exercises its power to safeguard and standardise the interpretation and application of federal law throughout the whole of Brazil.

The agravo em recurso especial e em recurso extraordinário (motion in special or extraordinary appeal) is the appeal that opposes, in certain circumstances, the denial of the hearing of the extraordinary or special appeal before the courts with jurisdiction to entertain them.

Lastly, the appeals against divergent decisions are those which aim to overcome and standardise possible divergences that may arise between the different bodies that make up the Federal Supreme Court and the Superior Court of Justice.

\section{Class Actions}

They are, in fact, very useful against companies and against the government. In Brazil, there is a very well developed class action system. ${ }^{32}$ Generally speaking, social regulation is the task of the legislative and executive branches of government. When something does not work or works badly, the judiciary should intervene, provoked by an individual party. However, a special feature of civil justice in Brazil, is the availability of a class action, where action may be filed by an entity expressly authorized by statutory law.

In fact, complex matters, involving rights which belong to a community or to a"group," are frequently handled within in the context of class actions. In class actions,

32 We could speak of a scientific revolution. Elton Venturi, Processo civil coletivo 24 (São Paulo: Malheiros, 2007). 
mainly when they are filed against the government, courts have to exercise the complex function of a social regulator. For example, an action was filed against the Prefeitura de São Paulo (São Paulo City Council) and the judge ordered it to reserve vacancies at a day care centre for mothers to leave their children when they go to work. ${ }^{33}$ The performance of regulatory role, often exercised by class actions, is being increasingly considered one of the main goals of civil justice in Brazil. ${ }^{34}$

Brazilian class actions $s^{35}$ are a rather well-developed field of our civil procedural law. Today, we have a sophisticated system of class actions. Brazilian legislation is very detailed in what concerns the kinds of rights which are protected; res judicata, ${ }^{36}$ lis pendens, ${ }^{37}$ and other important aspects are expressly dealt with.

Class actions can be considered a powerful device to improve access to justice and to balance a lack of power over companies and government. Class actions are a device to solve disputes over rights or duties found in society to which no one is specially or specifically entitled, and sometimes claims of various plaintiffs revolving around some legal issue.

Which point, or points, actually make class actions different from individual ones? Mainly two points: standing and res judicata. Rules of standing and res judicata are two sides of the same coin. A class action is brought by a representative claimant (collective standing) without the express consent of all the represented persons. And the outcome of the action shall bind the group as a whole.

In Brazil, class actions can only be brought by those identified by the statute: social unions, associations, prosecutors of the Public Prosecutor's Office (Ministère

33 See REsp 736.524/SP, Rel. Min. Luiz Fux, STJ, 21/03/2006.

34 On the subject: Rodolfo de Camargo Mancuso, Ação civil pública ( $9^{\text {th }}$ ed., São Paulo: Revista dos Tribunais, 2004); Pedro da Silva Dinamarco, Ação civil pública (São Paulo: Saraiva, 2001); Pedro Lenza, Teoria geral da ação civil pública (São Paulo: Revista dos Tribunais, 2003); Ricardo de Barros Leonel, Manual do processo coletivo (São Paulo: Revista dos Tribunais, 2002).

35 On the subject: Antonio Gidi, Coisa julgada e litispendência em ações coletivas (São Paulo: Saraiva, 1995); José Carlos Barbosa Moreira, Ações Coletivas na Constituição Federal de 1988, 61 Revista de Processo (1991); Ada Pellegrini Grinover, Código Brasileiro de Defesa do Consumidor: comentado pelos autores do anteprojeto ( $8^{\text {th }}$ ed., Rio de Janeiro: Forense Universitária, 2005); Ada Pellegrini Grinover, Ações coletivas ibero-americanas: novas questões sobre a legitimação e a coisa julgada, 361 Revista Forense (2002); Ada Pellegrini Grinover, A problemática dos interesses difusos in A Tutela dos Interesses Difusos (São Paulo: Max Limonad, 1984); Luis Manoel Gomes Jr., Curso de Direito Processual Civil Coletivo ( $2^{\text {nd }}$ ed., São Paulo: SRS Editora, 2008); Hugo Nigro Mazzilli, A defesa dos interesses difusos em juízo: meio ambiente, consumidor, patrimônio cultural, patrimônio público e outros interesses (24 $4^{\text {th }}$ ed., São Paulo: Saraiva, 2011).

36 Latin for "the thing has been judged," meaning the issue before the court has already been decided by another court, between the same parties. Therefore, the court will dismiss the case before it as being useless. Example: An Ohio court determines that John is the father of Betty's child. John cannot raise the issue again in another state. Sometimes called "res adjudicate" (Dec. 20, 2016), available at http://dictionary.law.com/Default.aspx?selected=1825 access 04/07/2011.

37 Latin for "a suit pending," a written notice that a lawsuit has been filed which concerns the title to real property or some interest in that real property (Dec. 20, 2016), available at http://dictionary.law. com/Default.aspx?selected=1172 access 04/07/2011. 
Public) and so on. Judges cannot evaluate the adequacy of representation on a caseby-case basis, as in the USA.

In the res judicata regime there is something special: specific rules of res judicata in Brazilian Class actions do not bind absentees if the judgment is not favourable to their interests. And, furthermore, there shall be no res judicata at all if there is a defeat due to insufficient evidence. The same class action can be brought again if new evidence is found and presented.

We talk about: a) diffuse rights, b) collective rights and c) homogeneous individual rights. These three types of rights correspond to three kinds of class actions, each with a slightly different procedure and scope of judgment.

1. A diffuse right ${ }^{38}$ belongs to a universe of indeterminate people, not previously connected and linked only by factual circumstances, e.g. we all have the right to breathe clean air or live in an ecologically balanced environment. ${ }^{39}$

2. A collective right ${ }^{40}$ belongs to a specific group, where persons are linked to each other by a pre-existing legal relationship, i.e. prior to the lawsuit, ${ }_{1}^{41}$ e.g. rights which belong to a specific professional category, such as lawyers ${ }^{42}$ or fishermen.

3. The homogeneous individual rights ${ }^{43}$ are the "old" rights (such as the droit subjectif of French Law) which can be the object of a collective treatment, if they have a common origin. ${ }^{44}$

An example of these rights emerges from the situation of clients of a bank from whom excessive fees have been charged; or that of a consumer enticed by false advertising, for example, to acquire beverages that contain prizes in the bottle

38 Mazzilli 2011; Pericles Prade, Conceito de interesses difusos 57-58 ( $2^{\text {nd }}$ ed., São Paulo: Revista dos Tribunais, 1987); Rodolfo de Camargo Mancuso, O município enquanto co-legitimado para a tutela dos interesses difusos, 12 Revista de Processo 49 (1987); Lúcia Valle Figueiredo, Direitos difusos na Constituição de 1988, 88 Revista de Direito Público 105 (1988); Grinover 1984, at 30-31; Celso Ribeiro Bastos, A tutela dos interesses difusos no direito constitucional brasileiro, 23 REPRO 40 (1981); João Carlos de Carvalho Rocha, Notas sobre a composição do dano ambiental no Brasil e nos Estados Unidos da América, 1 Revista da Procuradoria-Geral da República 174-175 (1992); Herman Benjamim, A insurreição da aldeia global contra o processo civil clássico. Apontamentos sobre a opressão e a libertação judiciais do meio ambiente e do consumidor in Ação civil pública lei 7.347/85 - Reminiscências e reflexões após dez anos de aplicação 93 (E. Milaré, ed., São Paulo: Revista dos Tribunais, 1995).

On this subject:REsp28222/SP 1992/0026117-5 rel.Mina.Nancy Andrighi (Dec.20,2016), availableat:https:// ww2.stj.jus.br/revistaeletronica/ita.asp?registro=199200261175\&dt_publicacao=15/10/2001.

On this subject, see Luiza Dias Cassales, Ação Civil Pública, 48 Revista da Ajufe (1996); Benjamim 1995, at 94; Mazzilli 2011.

41 Kazuo Watanabe, Código Brasileiro de Defesa do Consumidor: comentado pelos autores do anteprojeto 803 ( $8^{\text {th }}$ ed., Rio de Janeiro: Forense Universitária, 2005).

42 REsp 331403/RJ - Rel. Ministro João Otávio de Noronha, DJ 29/05/2006. Lawyers could only claim for something related to their professional group.

43 Mazzilli 2011.

44 Dinamarco 2001, at 60. 
tops but that, due to printing errors, nullify the right to the prize; and also those consumers who purchase vehicles produced with factory defects; or people who take loans that contravene national legislation or omit essential information. ${ }^{45}$

Those who can take the initiative of filing claims against (or suing) the state companies etc. "represent" a group of persons, the community or the whole society. They are specifically mentioned or named by statutory law. In Brazil, we did not adopt the system of adequate legitimacy or standing.

The effects of the final decision on the case affect all those who are "represented" unless the decision is based on a lack of evidence. In this case, the claim can be presented again.

The inversion of the burden of the proof is also possible, that is, it is possible for a judge to decide not to apply the rule, according to which, each of the parties has to produce evidence of the allegations of fact that he or she made. These proceedings are normally employed in environmental matters, consumer law, and in general questions or problems related to financial institutions.

\section{Costs and Funding}

Both the proceedings pending before the Federal Courts and those pending before the State Courts incur costs and expenses. There is a federal law, Act of Law no. 9.289/1996, that regulates the matter from the perspective of the Federal Courts. Each state has its own laws that deal with the matter regarding their respective courts. ${ }^{46}$

Despite the variation of the amounts in dispute, the rule of the head provision of Art. 82 of the 2015 Code of Civil Procedure is that "...the parties have to bear the expenses of the acts they perform or request in the proceedings, paying them in advance, from the start of the proceedings until the final judgment, or in the execution proceedings, until the acknowledged right has been fully satisfied."In the same provision, there is an express proviso relative to the "provisions concerning free legal aid," which are dealt with in great detail in Arts. 98 to 102 of the same code and have been introduced to replace the old legislation, still from the 1950s, which dealt with the subject, and was expressly revoked by Art. 1.072, III, of the Code.

Therefore, the rule is that the expenses incurred by those acts be paid for in advance by the one who requests the performance of the act or even when the

45 TRF 2a Região. Agravo em Ação Civil Pública 2006.02.01.004411-3, rel. Desembargador Federal Frederico Gueiros, DJ 13/06/2007.

46 A recent survey reveals, for this purpose, the disparity that exists between the various Brazilian states, where it is possible to find, for the same claim value (the survey uses as a reference a claim of $\mathrm{R} \$ 100,000.00$, equivalent to US\$25,000.00, using an exchange rate of $\mathrm{R} \$ 4,00$ to the US\$ 1,00 ), a difference of almost $R \$ 7,000.00$ (equivalent to US\$ 1,750.00) in the payment of court costs between the States of Piauí (the most expensive) and the Federal District (the cheapest) (Dec. 20, 2016), available at http://www.migalhas.com.br/Quentes/17,MI235925,91041-PI+e+Estado+com+custas +judiciais+mais+caras+do+Brasil. 
act is performed at the request of the Public Prosecutor's office as "inspector" of the legal system (custos legis). When the judgment is entered, it is determined who is responsible for the payment, which is, in accordance with the majority of jurists, based on causality, i.e. it is the one who gave rise to the cause of action who must pay the expenses and not necessarily the one who is defeated in court. ${ }^{47}$

According to Art. 84, procedural costs include the costs of procedural acts, reimbursements for trips, compensation of the retained expert and witness allowances. Besides those, counsel fees will also be determined in the judgment - known as loss of suit fees, - which will be paid upon conclusion to the lawyers themselves and not to the parties (Art. 85). The values of these fees vary, in disputes involving natural persons, from 10 to $20 \%$ of the amount in dispute and, when it involves legal persons, percentage that vary in the same range from 10 to $20 \%$ and from 1 to $3 \%$, in accordance with the value involved in the action.

An important innovation introduced by the new Code of Civil Procedure in this regard is the possibility of increasing the loss of suit fees when there is an appeal. Although the sums cannot exceed the percentage limits mentioned, the idea is that the possibility of increasing the fees will lead to a reduction in the number of appeals.

As has already been mentioned, the new Code of Civil Procedure introduces extensive rules regarding free legal aid, thus establishing one of the chief constitutional principles of civil procedural law, Art. 5, LXXIV, of the Federal Constitution. According to the head provision of Art. 98, "a natural or legal person, whether Brazilian or foreign, who lacks sufficient funds to pay court costs, procedural costs and counsel fees will be entitled to free legal aid, pursuant to the law." Paragraph 1 of the same provision states that free legal aid includes: "I - judicial fees and costs; II - postage stamps; III - publishing expenses in the official press, waiving publication in other media; IV - compensation due to the witness who, when employed, shall earn a full salary from the employer, as if working; $V$ - expenses incurred with genetic testing DNA and other tests that may be deemed essential; $\mathrm{VI}$ - fees of counsel and courtappointed expert, and the compensation of the interpreter or translator appointed to submit the Portuguese translation of a document drafted in a foreign language; $\mathrm{VII}$ - the cost of preparing a statement of calculation, when required for instituting execution proceedings; VIII - the deposits required by law to lodge appeals, file actions and the performance of other procedural acts inherent to the exercise of the right of due process and the right to be heard; IX - the fees owed to notaries or registrars arising from the performance of registrations, declarations or any other notarial act required for the enforcement of a judicial decision or for the continuity of the judicial proceedings in which the benefit of free legal aid has been conceded."

47 While this is the understanding of the majority, one of the authors of this article has proposed that the subject be reanalysed in view of the important novelties introduced by the new CPC on this matter, including, but not only, § 2 of Art. 82. On this discussion, see Scarpinella Bueno, Manual de direito processual civil, at 145-150. 
A claim formulated by a natural person is presumed to be true, with the certainty that if doubts arise and in other cases, the judge must make a decision regarding the request after duly hearing the other side, in accordance with the principle of audi alteram partem.

\section{Enforcement Proceedings}

The 1973 Code of Civil Procedure innovated when it unified the procedure and system for the enforcement of judicial and extrajudicial enforceable instruments.

Over the more than twenty years that the code was in effect, however, profound legislative changes were made and the distinction between the procedure and system of the two became redundant. The new Code of Civil Procedure ended up assuming this profound transformation, clearly distinguishing between what it generally called the "enforcement of the judgment" and the "enforcement proceedings."

The so-called "satisfaction of the judgment" must be understood to be the phase of the proceedings in which the judge's enforcement activities prevail aiming to realise that which was acknowledged in the judicial enforceable instrument. According to Art. 515 of the new Code of Civil Procedure, judicially enforceable instruments are: "I- decisions rendered in civil proceedings that acknowledge the enforceability of the obligation to pay a sum, to do, not to do, or to deliver something; II - the ratification by the court of a resolution by the parties; III - the ratification by the court of an out-of-court resolution of any nature; IV - the final judgment of distribution and the distribution certificate, exclusively in relation to the administrator, the heirs and successors, by way of partial or universal succession; $\mathrm{V}$ - the claim of the officer of the court when the court costs, emoluments and fees have been approved by a court order; $\mathrm{VI}$ - a final judgement of conviction; VII - an arbitral award; VIII - a foreign judgment confirmed by the Superior Court of Justice; IX - a foreign interlocutory decision after the granting of the exequatur of the letter rogatory by the Superior Court of Justice."

The rule is that, at the request of the judgment creditor, the debtor will be notified through his or her lawyer to pay, do, not do or deliver the things, in accordance with provisions of the judicially enforceable instrument. Should said determination not be complied with, enforcement procedures, which will vary according to the type of obligation, will be initiated. When dealing with obligations to do or not to do, the imposition of a coercive penalty is extensively regulated by the new Code of Civil Procedure. As regards the obligation to deliver a thing, the preferred means of enforcement is the search and seizure (for movable property) or the taking of possession (for immovable property). When the obligation refers to the payment of a sum, there is a broader range of techniques that seek to expropriate, within limits, the assets of the judgment debtor. Among these, the provisions of Art. 854 should be noted, with the so-called "on-line levy of execution," i.e. electronic, carried out with the exchange of information between the judge and the Banco Central do Brasil (Brazilian Central Bank), 
the highest Brazilian monetary authority, postponing the testimony of the debtor until after the effective freezing of funds held by the debtor. When the levy of execution involves assets other than money, it is necessary to appraise them and to adopt measures for their alienation so that, with its acquisition or by raising the respective sum, the judgment creditor's claim will be satisfied. The preferred mechanism of expropriation of the new Code of Civil Procedure is the electronic auction (Art. 882).

The possible defence of the judgment debtor - known as "challenge" - is filed in the same proceedings and does not depend on the prior posting of a bond (required only for the suspension of the performance of enforcement acts).

The so-called "enforcement proceedings" are based on the extrajudicially enforceable instruments, understood to be those that do not depend on the declarations or agreement of the courts to be established and enforced. The instruments provided for in Art. 784 of the Code of Civil Procedure are the following: "I - drafts (bills of exchange), promissory notes, bills, bonds and cheques; II - public deeds or other public documents signed by the debtor; III - private documents signed by the debtor and by two (2) witnesses; IV - transaction instruments ratified by the Public Prosecutor's Office, by the Public Defender's Office, by the Attorney General's Office, by the lawyers of the parties to the transaction or by a conciliator or mediator accredited by the court; $\mathrm{V}$ - the contract guaranteed by a mortgage, pledge, antichresis or other secured interest and that guaranteed by a bond; $\mathrm{VI}$ - the life insurance contract in case of death; $\mathrm{VII}$ - the claim arising from emphyteusis; VIII - the claim, proven with documental evidence, arising from the rental of real property, as well as associated charges, such as condominium fees and expenses; IX - a certificate of overdue tax liability of the Tax Authorities of the Federal Government, State Governments, Federal District and Municipal Districts, corresponding to the liabilities registered pursuant to the law; $\mathrm{X}$ - the debts relative to ordinary and extraordinary contributions to a residential condominium, set forth in the respective condominium bylaws or approved at a general meeting, provided there is documentary evidence to prove them; XI - a certificate issued by a notary public or registry office relative to fees and other expenses due for acts performed by them, as determined in the fee schedule established by law; XII - all other instruments to which, by express provision, the law attributes enforceability."

In these cases, as the proceedings are initiated with the submission of the extrajudicially enforceable instrument by the judgment creditor - Arts. 798 and 799 of the new Code of Civil Procedure indicate the rules that must be observed in the drafting of the complaint, - the judgment debtor is to be summoned in order to perform the obligation, the deadline varying in accordance with the type of obligation. If the obligation has not been performed by the end of the deadline, the enforcement acts are commenced in an identical manner to the satisfaction of the judgment.

The defence of the judgment debtor is effected by means of the so-called "motion to stay de execution" the filing of which does not depend on the prior posting of a bond and does not automatically suspend the performance of enforcement acts. 
In order to suspend the performance of the enforcement procedures, it is necessary to post bond, in addition to showing relevant grounds and losses that will be incurred by the judgment debtor. When dealing with the payment of a sum, the judgment debtor may choose, as an alternative to the filing of a motion to stay the execution, to deposit $30 \%$ of the value of the debt and request that the remainder be paid in six monthly instalments adjusted for inflation and with interest of $1 \%$ per month added, pursuant to art. 916 . Hence, the precise terms of default on payments.

\section{Arbitration and ADR}

Brazilian jurists have, gradually, been advocating the need to give a broad interpretation to item XXXV of Art. 5 of the Federal Constitution, according to which "the law shall not exclude any injury or threat to a right from the consideration of the Judicial Power, ${ }^{\prime \prime 48}$ to include in it not only access to state courts, provided by the judicial branch, but also other forms of dispute resolution, even if not in the sphere of the states or, more restrictively, not judicial. ${ }^{49}$

In this context, the paragraphs of Art. 3 of the new Code of Civil Procedure should be emphasised, according to which the use of alternative means of dispute resolution is expressly encouraged, with the explicit mention made of mediation, conciliation and arbitration, which do not exclude other methods to achieve the same end.

To achieve that goal, the new Code of Civil Procedure implemented profound changes to the structure of common procedure, making it a rule to summon the defendant no longer to file a defence but, otherwise, to appear at a conciliation and mediation hearing. The deadline for the answer to be filed, in order to strengthen the importance of that act, shall only start running upon the breakdown of the negotiations conducted at the hearing.

Such hearings, it is important to note, must be carried out at a location other than the judicial chambers - at the so-called "Judicial Centres for the Amicable Dispute Resolution" - and be conducted by mediators and conciliators, elevated, not by chance, to "officers of the court" by Arts. 165 to 175 of the new Code of Civil Procedure.

Notwithstanding, item V of Art. 139 is explicit in authorising the judge to "foster, at any moment, an amicable resolution, preferably with the assistance of court conciliators and mediators" as can be seen, for example, at the start of the trial. The reading of Art. 359 is rather significant in this regard: "At the outset of the trial, the judge shall attempt to reconcile the parties, regardless of any previous usage of other methods of amicable dispute resolution, such as mediation and arbitration."

On the other hand, during the vacatio legis of the new Code of Civil Procedure, there was the enactment of Law no. 13.140/2015, which governs extrajudicial

\footnotetext{
48 Available at http://www2.senado.leg.br/bdsf/item/id/243334.

49 To this effect, see Wambier 2016, at 63; Scarpinella Bueno, Manual de direito processual civil, at 91-92.
} 
mediation to be carried out by administrative person $\mathrm{s}^{50}$. Some amendments were also made to Law no. 9.307/1996, which governs arbitration, to broaden its scope, with special note to the viability of political and administrative persons opting for that way of resolving their disputes, which had been until that moment restricted, though not without some controversy, to private persons.

\section{The Role of Academia}

The situation of academia in Brazil is rather special. Its role is very significant. In Brazil, there are more than 1,400 law faculties. It is easy to figure out the quantity of professors needed. Among them all, not just a few become important figures. It is also interesting to mention that professors are usually also lawyers, judges, i.e., they have another occupation related to the practice. Although this can, according to the government bodies which control the quality of Brazilian universities, compromise academic activities, this is our reality with just a few exceptions.

Legal writers have a great deal of influence in the result of legal disputes. Academic books are referred to and sometimes, very often, extracts are quoted in judicial decisions. Very often, law suits contain legal opinions written by academics, which can have an expressive influence on the decision

An overview of the Brazilian situation shows that law is a concept supported by statutory law, case law and legal writing.

\section{Statistics}

The drafting of the new Code of Civil Procedure was not officially based on any statistics. Its amendments are much more the product of some consensus between scholars and practitioners than a response to statistical studies that preceded it, and that may have pointed to possible problems or bottlenecks in the system.

For that very reason, Art. 1.069 of the new Code of Civil Procedure determines that "The National Council of Justice shall periodically conduct statistical surveys in order to evaluate the effectiveness of the rules set forth in this Code," a rule which has been applauded by commentators of the new law ${ }^{51}$.

With regard to the methods of alternative dispute resolution, our attention is also drawn to $\S 4$ of Art. 167 of the new Code of Civil Procedure, according to which the results attained by conciliators, mediators, as well as by mediation and conciliation chambers are to be disclosed and assessed at least annually.

As it is a federal law, the rules contained in Arts. 35 to 40 concern federal administrative entities, that is, the Federal Government itself and its respective administrative entities. Arts. 32 to 34 of said Law, however, reveal the pragmatic nature of those rules for the federal entities with the aim of incentivising them to create, through their own rules, a similar system.

51 Consult, among others, the following works: Wambier 2016, at 1.721. 
However, the above affirmations do not mean that there are no statistics of procedure in Brazil. There are a number of initiatives of the National Council of Justice and of the courts themselves that allow for the analysis of statistics that enables one to draw conclusions, based on those facts, on the workings of certain modifications introduced more recently in the Brazilian system. This is the case of, for example, the statistics disclosed by the Federal Supreme Court regarding general repercussion, a true filter of the admissibility of the extraordinary appeal lodged before said court and which enable the visualisation of a notable reduction in the number of those appeals. ${ }^{52}$

Within the scope of the National Council of Justice, the survey named "justice in numbers" deserves mention due to its importance, being the main source of official statistics of the judicial branch and which, since 2004, has been publicizing "the reality of Brazilian courts in great detail with regard to structure and litigation, in addition to the essential indicators and analyses needed to support Brazilian Judicial Management.".53

\section{Comparative Observations}

A quick word is needed to criticize a certain trend which exists now in Brazil to assert that our country is being transformed into a Common Law jurisdiction: it is by no means true. This is said because our New Civil Procedure Code (2016) creates three cases where the precedent is binding. These three precedents are those decisions given in lawsuits where the question of law is the same (absolutely the same) for a whole community, as usually happens in consumer law. So, according to the new CPC, the precedent has to be used as basis for all the future decisions on the same question of law.

On the one hand, this is not something entirely harmonious with civil law traditions. On the other hand, it is not enough to say we are becoming a Common Law country. In countries like Germany or Austria it would be considered "natural" or it would perfectly respond to fair expectations to respect a precedent given or produced to solve a question of law which involves hundreds people not only to solve their personal cases but also to solve future identical cases.

In Brazil, the rule that every judge should decide according to his or her own views on what would be the right interpretation of statutes was taken too far. This is why a few provisions were conceived by the legislator creating three hypotheses where it is obligatory to follow precedent, under penalty of "reclamação." Reclamação is a special kind of process specially conceived with the sole purpose of challenging decisions that disrespect the authority of courts, including these precedents.

52 Available at http://www.stf.jus.br/portal/cms/verTexto.asp?servico=estatistica\&pagina=REAIProce ssoDistribuido. Even so, there are, in April 2016, 41,326 extraordinary appeals and appeals derived therefrom pending trial before the Federal Supreme Court (Dec. 20, 2016), available at http://www. stf.jus.br/portal/cms/verTexto.asp?servico=estatistica\&pagina=acervoinicio.

53 Available at http://www.cnj.jus.br/programas-e-acoes/pj-justica-em-numeros. 
Furthermore, the new Brazilian CPC (2016) has several provisions stating the obvious, such as: courts should produce consistent and stable case law.

A considerable number of our legal writers say that this has nothing to do with Common Law and they are right. These efforts of the legislator just show there is an evident intention of correcting this severe distortion: to say that a judge can base her or his decision on his own understanding of law does not mean at all that case law of superior courts must not be respected. And also, more importantly, superior courts cannot change their opinions very often. Case law must change to adapt law to social changes and those take decades and sometimes centuries to take place, not weeks or months.

So, all these new provisions, of the new Brazilian CPC which came into force on 18 March 2016, and which could at first sight be seen as a "trend" towards Common Law, are nothing but a way of controlling the lack of consistency of Brazilian law, the lack of uniformity and stability of case law and mainly the lack of predictability.

\section{Cultural Observations}

From a cultural point of view, it is worth noting that many of the novelties introduced by the new Code of Civil Procedure depend, in order to become effective, on a profound alteration in the performance of the professionals and scholars of Brazilian civil procedural law.

In this regard, two points should be highlighted: the stimulus given by the Code, from Art. 3, to the means of alternative dispute resolution and the observance of decisions rendered by the superior courts, regardless of their binding nature or of the express constitutional provision to this effect.

In relation to the first point, one should recall that the common procedure of the new Code of Civil Procedure introduces, as a rule, the service of summons upon the defendant to appear at a conciliation or mediation hearing. This act is so important that the deadline for the defendant to file his or her defence will only start running if a possible amicable resolution between the parties fails. In order for the rule to have effective applicability, it is important that law professionals, both the new officers of the courts, conciliators and mediators (Arts. 165 to 175 of the new (PC), are fully aware of the advantages and usefulness of said act.

As to the observance of the decisions of the superior courts, the change in culture and attitude must come from the courts themselves. For over fifty years, the Federal Supreme Court has been publishing precedents with the purpose of not only disclosing its understanding on the matters adjudged but also so that they, in some way, be observed by the other courts. However, there is no indication that this model has brought about any improvement or greater efficiency in the Brazilian civil procedure system, much to the contrary. As this constitutes a fundamental point for the success of the new Code of Civil Procedure, it is important for law professionals in 
general establish the conditions required for the proper establishment, application and prevalence of these precedents.

\section{International Matters and BRICS Cooperation in Civil Procedure Perspectives}

The new Brazilian Code of Civil Procedure innovates when it expressly establishes rules of "international cooperation" in Arts. 26 to 41, including direct assistance. ${ }^{54}$

By "international cooperation" one means the set of techniques that allow two states to cooperate with each other for the enforcement, outside their borders, of court orders issued by one of them.

Art. 26 establishes that international cooperation be governed by Treaties to which Brazil is a party - and, in the absence of a Treaty, on the basis of reciprocity manifested by diplomatic means ( $\$ 1$ ), except in the case of the confirmation of a foreign judgment $(\S 2){ }_{1}^{55}$ - in compliance with the principles listed in its items: respecting the guarantees of the due process of law in the requesting State; equality of treatment of citizens and foreigners, resident or not in Brazil, with regard to access to justice and the prosecution of the actions, assuring legal assistance to the needy; procedural publicity, except in the cases of confidentiality as provided for in Brazilian legislation or in the requesting State; the existence of a central authority for the receiving and conveyance of the cooperation requests and spontaneity in the conveyance of information to foreign authorities.

International cooperation may have, in accordance with Art. 27 of the new Code of Civil Procedure, the following subject matters: summons, subpoenas, and judicial and extrajudicial notifications; the gathering of evidence and information; ratification and enforcement of decisions; the granting of urgent judicial relief; international legal assistance or even any other judicial or extrajudicial measure that is not forbidden under Brazilian law.

\section{Conclusion}

Currently, Brazil is living a very serious crisis both ethical and economic, in the political sphere, and the population puts all its hope in the judiciary branch. Brazilian

54 According to Art. 30 of the new Code of Civil Procedure, direct assistance may deal with, in addition to those arising from Treaties to which Brazil is a party, the following subject matters: "I - obtaining and furnishing information regarding the legal system and the administrative or court proceedings, whether pending or closed; II - gathering of evidence, unless the remedy is adopted in proceedings, pending abroad, over which Brazilian courts have exclusive jurisdiction; III - any other judicial or extrajudicial remedy not forbidden by Brazilian statutory law."

55 The court with jurisdiction to ratify the foreign judgment and for the concession of the exequatur to the letters rogatory is the Superior Court of Justice (Art. 105, I, "i," of the Federal Constitution), which will, to these ends, observe both the procedure established in Arts. 36 and 960 to 965 of the new Code of Civil Procedure, and the provisions of its own Internal Regulations. 
judges have a career, which begins by passing a public admission exam where there is no political bias. In recent years, they have shown that they are independent and entirely fulfil the needs and expectations of Brazilian society.

In the last twenty years, civil procedure has been experimenting with a deep and structural process of change. These changes have led to the creation of the new CPC (2016) which encompasses several novelties adapted to the Brazilian reality, even if sometimes clearly inspired in comparative law. The excessive quantity of lawsuits and existing appeals is a problem that no statutory law is able to solve. But, from another perspective, this means that access to justice is widespread in Brazil, which can evidently be seen as a positive aspect.

The authors hope that the general lines drawn have managed to achieve their aim, which is to enable foreign scholars of procedural law to become acquainted with Brazilian civil procedural law, its functions and the challenges that the new Code of Civil Procedure, which came into effect in March 2016, brought about for Brazilian civil procedure lawyers and scholars.

\section{References}

Aragão E.D.M. de. Comentários ao Código de Processo Civil. Vol. 2 ( $2^{\text {nd }}$ ed., Rio de Janeiro: Forense, 1976).

Arruda Alvim J.M. de. Manual de direito processual civil. Vol. 2 ( $9^{\text {th }}$ ed., São Paulo: Revista dos Tribunais, 2005).

Barbosa Moreira J.C. Notas sobre alguns aspectos do processo (civil e penal) nos países anglo-saxônicos, 92 Revista de Processo (1998).

Bedaque J.R. dos S. Direito e processo: influência do direito material sobre o processo $\left(2^{\text {nd }}\right.$ ed., São Paulo: Revista dos Tribunais, 1994).

Benjamim H. A insurreição da aldeia global contra o processo civil clássico. Apontamentos sobre a opressão e a libertação judiciais do meio ambiente e do consumidor in Ação civil pública lei 7.347/85 - Reminiscências e reflexões após dez anos de aplicação (E. Milaré, ed., São Paulo: Revista dos Tribunais, 1995).

Carneiro A.G. O novo Código de Processo Civil: breve análise do projeto revisado no Senado, 194 Revista de Processo (2011).

Cassales L.D. Ação Civil Pública, 48 Revista da Ajufe (1996).

Cintra A.C. de A. Teoria geral do processo ( $25^{\text {th }}$ ed., São Paulo: Malheiros, 2009).

Costa M.L. da. Breve notícia histórica do direito processual civil brasileiro e de sua literatura (São Paulo: Revista dos Tribunais, 1970).

Didier F. Jr. Curso de direito processual civil. Vol. $1\left(10^{\text {th }}\right.$ ed., Salvador: JusPodivum, 2008).

Dinamarco C.R. Instituições de direito processual civil. Vol. 1 (6 $6^{\text {th }}$ ed., São Paulo: Malheiros, 2009).

Dinamarco P. da S. Ação civil pública (São Paulo: Saraiva, 2001). 
Figueiredo L.V. Direitos difusos na Constituição de 1988, 88 Revista de Direito Público (1988).

Gidi A. Coisa julgada e litispendência em ações coletivas (São Paulo: Saraiva, 1995).

Grinover A.P. A problemática dos interesses difusos in A Tutela dos Interesses Difusos (São Paulo: Max Limonad, 1984).

Lenza P. Teoria geral da ação civil pública (São Paulo: Revista dos Tribunais, 2003).

Leonel R. de B. Manual do processo coletivo (São Paulo: Revista dos Tribunais, 2002).

Mancuso R. de C. Ação civil pública ( $9^{\text {th }}$ ed., São Paulo: Revista dos Tribunais, 2004).

Prade P. Conceito de interesses difusos ( $2^{\text {nd }}$ ed., São Paulo: Revista dos Tribunais, 1987).

Rocha J.C. de C. Notas sobre a composição do dano ambiental no Brasile nos Estados Unidos da América, 1 Revista da Procuradoria-Geral da República (1992).

Scarpinella Bueno C. Curso sistematizado de direito processual civil. Vol. 1 ( $8^{\text {th }}$ ed., São Paulo: Saraiva, 2014).

Talamini E. Tutela de urgência no projeto de novo Código de Processo Civil: a estabilização da medida urgente e a "monitorização" do processo civil brasileiro, 209 Revista de Processo (2012).

Tucci J.R.C. e. Tempo e processo (São Paulo: Revista dos Tribunais, 1997).

Venturi E. Processo civil coletivo (São Paulo: Malheiros, 2007).

Wambier L.R. et al. Curso avançado de processo civil. Vol. 1 (9 $9^{\text {th }}$ ed., São Paulo: Revista dos Tribunais, 2007).

Wambier T.A.A. Primeiros comentários ao novo Código de Processo Civil $\left(2^{\text {nd }}\right.$ ed., São Paulo: Revista dos Tribunais, 2016).

Watanabe K. Código Brasileiro de Defesa do Consumidor: comentado pelos autores do anteprojeto ( $8^{\text {th }}$ ed., Rio de Janeiro: Forense Universitária, 2005).

Zavascki T.A. Reforma do sistema processual civil brasileiro e a reclassificação da tutela jurisdicional, 88 Revista de Processo (1997).

\section{Information about the authors}

Teresa Arruda Alvim Wambier (São Paulo, Brazil) - Full Associate Professor, Faculty of Law, Catholic University of São Paulo (R. Hildebrando Cordeiro, 30, Ecoville, Curitiba/PR, 80740-350, Brazil; e-mail: teresaarrudaalvim@wambier.com.br).

Cassio Scarpinella Bueno (São Paulo, Brazil) - Full Associate Professor, Faculty of Law, Catholic University of São Paulo (R. Cayowaá, 759, cjs. 31/32, Perdizes, São Paulo/SP, 05018-001, Brazil; e-mail: cassio@scarpinellabueno.com.br). 